\title{
Transformation of Everydayness \\ in the Modern Media Society
}

\author{
Alla V. Drozdova* \\ University for the Humanities \\ 24a Surikova Str., Ekaterinburg, 620144, Russia
}

Received 19.03.2015, received in revised form 19.05.2015, accepted 22.07.2015

Characteristic features of modern society-emerging of new forms of sociality, network communication - have given rise to "rediscovery" of everydayness initiated by modern human sciences. The search of new foundations for everyday reality studies came to replace metaphysical constructs of the previous age. Admitting polyvariety of the world, its being heterogeneous, social theory disclosed a complex structure of everydayness, its inability to be narrowed down to a certain abstract characteristics. Since it is in the man's everyday world where transformations typical for the society manifest themselves, manifoldness of individual experiences and practices has become the subject matter of interdisciplinary analysis.

Currently, with the development of new media and the increased contact density in daily life not only the nature of social communication has changed, but also the impact areas of visual information. Visibility has become an important part of everyday life, its images represent the lifestyle and types of relations, design the perception and the structure of the human consciousness, their particular way of seeing the world.

In the epoch of "media reality", everydayness is losing its stability and sustainability being ceaselessly exposed to superfast, mobile visual images. They act as a kind of patterns, models of everyday behaviour. Due to "technical repeatability" images can integrate into our life in no time replacing immediate experience, giving rise to the phenomenon of reality simulation. Through constructing and replacing reality, simplifying communication language, visual images are becoming, in essence, some universal cultural code and generate new ways of social interaction and communication acting herewith as a condition for social communities formation.

Keywords: everydayness, visuality, self-identification, new media, public/private.

DOI: 10.17516/1997-1370-2015-8-9-1834-1846.

Research area: philosophy.

Everydayness as a special subject area of studies gained a foothold quite late, only in the second half of the $20^{\text {th }}$ century. In general, interest in the trivial, everyday aspects of daily life was connected with the crisis of rationalism that questioned the belief in historical progress and reasonable meaning of human existence. If earlier in social sciences the private life of man was considered as an element, "a cell" of an integral system, which was denied legitimacy by virtue of its inauthenticity and imperfectness, the development of phenomenological and

(C) Siberian Federal University. All rights reserved

* Corresponding author E-mail address: drozdovaalla@mail.ru 
hermeneutical schools has made human life an object that requires special attention.

Recent philosophy has set two important methodological questions: 1. How should we understand the reality of everyday life, if sustainable, stable relations of its existence are destroyed, lose their meaning? 2. What are the methods of analyzing everyday life, if in the context of modernity old traditional methods do not work?

Thus, in his works N. Luhmann denies the validity of appeals to the traditional understanding of the society and offers to "redefine the society", to consider it as a system consisting of specific people and their relations. In other words, the logic of studying the changing world coincided with the logic of the study of everydayness, which was released from the framework of the total classical discourse and was becoming a special independent object of research. The interest to the "basic level of the social" is typical for works of both Western (B. Waldenfels, H. Lefebvre, N. Elias, J. Habermas) and Russian authors (V. Volkov, N. Kozlova, A. Panarin). Methods of studying everydayness have been changing correspondingly, the main attention is now paid not to practice, but practices, self-evident and clichéd actions as the phenomenon of "the living world".

In the modern social theory, "rediscovery" of everyday life takes place under the sign of "a practical turn", which introduces significant changes in the definition of everydayness. Earlier in the phenomenological approach, everydayness was declared "supreme reality" of human existence, but they start to see it as an isolated world of everyday routine and nonreflexive actions. First of all, this is due to a different understanding of the nature of the social, awareness of "polytheism" of everyday life, the multiplicity of its experiences, attitudes, mentalities and language practices. Such a shift in methodological settings allows to pay attention to what previously seemed unimportant: on the practices of everyday life, which "are not embodied in any formal institution and form a kind of "free zones" protected or protecting from institutional pressures" (Kozlova, 1998).

Therefore, new areas of studying everydayness are revealed, there is an interest in a variety of formats (practices) of everyday actions through which the actor "captures" the reality. According to O. Kharkhordin, "a pragmatic turn focuses on processes involved, and not the essences", its theorists P. Bourdieu, M. Foucault, A. Giddens, L. Boltanski and L. Thévenot are interested in the local order of "the approved interaction" in everyday life (Kharkhordin, 2007). The theory of the habitus of Pierre Bourdieu, who made an attempt to identify and then structure the "intangible" nature of everydayness, is especially interesting. Bourdieu examines everydayness as a human-determined system of everyday practices, which express the main human dispositions: socio-psychological preferences, tastes in relation to objects and values. Everydayness, according to Bourdieu, is a reaction manifested in preferences and actions of active subjects, a response to the repressive (standardizing) social reality. What is meant here is, in fact, dual structuring. On the one hand, the society and its social institutions are the reason for daily practices (the source of the habitus), and, on the other hand, the sociocultural standards and values pass through the system of human ideas and preferences. Having passed through the habitus "filter", having been altered and modified, they build a structure of social relations that are important for the human and that define their place in the society.

As part of a practical paradigm, M. Certeau develops his own method of analyzing everyday culture, its "details", namely "everyday ways of doing things": the practice of consumption, typical models and methods of users' behaviour. In his 
work "The Practice of Everyday Life", Certeau first of all, points at the fact that everyday life is not so much the implementation of standards and forced obeying the rules and schemes, but improvisation, "tricks", "poaching", "procedures of everyday ingenuity" of those, who are "usually considered to be doomed to passivity". Therefore, the researcher's interest shifts from passive consumption of products to anonymous creativity arising from the gap created by the practice of using these products (Certeau, 2013).

Certeau proposes to investigate the phenomenon of everydayness in the context of the consumer society, where consumption is not only an important feature of post-modern capitalism, but also the main mechanism of functioning and realization of human needs. It is the act of consumption that M. Certeau calls "a tactical attack of the system": alignment of the individual's self-made world, where the consuming subject is opposed to mass consuming bureaucratic urbanized society. To be successful (in reality or pretending to be) in opposition to the totality, human is forced to learn the art of everyday life, that is, adapt to the social environment of by all possible available means. Therefore, the distinctions between production and consumption in the culture of everyday life are eliminated. The art of everyday life is constant balancing between the two main spheres of human existence: the external public life and the internal individual life.

According to Certeau, "the daily life itself is filled with miracles: it is life in full swing", Brownian motion of disobedience, micro resistance, which mobilizes the resources hidden in ordinary people, and thus resets the original boundaries of the expansion of power. Without excluding the expansion of the economic order from television to urbanization, Certeau considers another hidden, invisible production of customers that comes from the self-interest of individuals and leads to countless changes in the structure of everyday life. M. de Certeau introduces it as "the culture of everyday life" meaning person's ability to resist, confront undesirable influences of the environment or the social system. In this case, adaptation is nothing but manipulating a person with implementation schemes imposed from outside or using them to one's own advantage.

The issue of the everyday life's role is becoming increasingly important due to the rapidly developing information processes and communication technologies that influence it. In the "flowing modernity", everydayness no longer retains its function of the stability refuge. Its flexibility and mobility cannot keep up with the fast changes of information, material, cultural and social environment. The emergence of new qualities of social life such as technological changes, globalization, mega-urbanization, consumerism, flexible forms of work, transformation of the private sphere and saturation with visuality has led to the situation that at the level of everyday practice, people have become more keenly aware of their rapidly changing and in many respects strikingly new "living world". All these changes have been reflected in theories of different researchers (Habermas, Luhmann, Giddens, M. Maffesoli, etc.), which substantiate the idea of the procedural nature of society, prove that today, in the conditions of alternativeness and instability of social and cultural principles, not the study of holistic social systems, but the study of the processes of continuously changing social reality are prevailing. Modernity of the society "is characterized not so much by group or institutional regulations, functioning of traditions or customs, canons, collective habits and values, as by the significance of behavioural rules situationally generated by the individual for himself that he awaits others will also understand (Gudkov 2012). In this regard, conceptualization of everydayness in the context of socio-cultural 
transformations of the society gain particular significance.

The issue of the transformation of everyday life, its variability is one of the most ambiguous ones. The fundamental contradiction of everydayness is the repeatability (monotony) of actions, which at the same time are the constants of changes. The experience of everyday life is associated with the past and the future, and constitutes "a deep structure" with the modernity. Thus, on the one hand, it is characterized by continuity and traditions, which arm people with habits, expectations, specific sequence of actions and thereby ensure not only the stability of the society existence, but also make human life safe and comfortable. On the other hand, it is characterized by variability and temporary nature of actions in the modern mobile world there are many situations, which a person cannot resolve on the sensory-rational level, referring to the standard method of "ordinary interpretation" (transformation of the unknown in the clear, of the impossible into the possible). In this case, the sphere of everyday life can becomeirrational, move into other areas: fantasy, faith or psychological frustration. For example, in the course Russian society transformation, when everyday practices have changed, there is a rise of "the lower level of Soviet psychology", which means that people mentally continue to live in terms of the Soviet paradigm, communicate "using the language of the last century, a different reality, a non-existent country".

Despite some sustainability of the everyday life forms, conditions in which that experience exist are mobile, open and connected with changing visual and social practices typical for the modern epoch. The main features of postmodernity are: social dynamics, high mobility and the absence of a fixed place; flexible network organization without rigid hierarchy; manipulation of identity including its imitation. The basic feature of the modernity, according to H. Lubbe is "the reduction of staying in the present", while in a dynamic civilization the past quickly becomes the past and it becomes increasingly difficult to recognize familiar signs of the present, while the horizon of the forecast future is getting closer. The process of reducing intervals of the human life cycle leads to the fact that the "space of life experience and the horizon of the future become incongruent" (Lubbe, 1994). The cultural consequences of the present experience aging rate are very significant and contradictory: it is specific sensitivity to historical changes, and, as a consequence, raising demand for what has been "tested by time", an attempt to save, to keep the past, "to museumificate" it. Social dynamics represents another important feature of the modernity: a high level of uncertainty and "the fact that people have lost the feeling of ontological fullness of existence" (Kurennoi, 2007). Modern man is not only included in the complex organized systems of activities related to the growth of personal competencies, but also performs a number of different social roles included in complex communicative structures. However, none of these roles captures him completely, resulting in a permanent crisis of personal identity of modern man.

A. Schütz has determined that everyday life is constantly changing, it is like a river that one cannot step twice into. It is not the presence of strict norms, patterns and customs limiting freedom that become the problem of modern man, but rather the lack of the latter as a result of the abundance of the options. Modern man cannot rely anymore on the existing structures of everyday life that were formed once. He must choose them for himself out of the variety of possible options. Thus, in modern society, everydayness cannot be regulated by the previously formed traditional and stable patterns of interpretation of reality, stereotypes of behaviour and relationship 
structures. They are constantly exposed to the deconstruction on the part of social institutions that provide the design and implementation of new myths and stereotypes using media channels, advertising and popular culture.

Everydayness is characterized by "pluralism of small life choices", microevents that are "stitched" by a set of communications. Therefore, we do not consider "everydayness" as a universal concept that applies to all ages and cultures, but as a local and specific concept associated with "modernity". Such study is particularly attractive due to the fact that the major part of everyday life at this level is visible, observable, and therefore may open to the productive visual techniques, including photography, cinema and advertising.

Social establishment and procedurality of "the living world" organizes the semantic space of human life, which is reproduced in a qualitatively new forms of everyday practices changing under the influence of the media, as well as technical means of communication. Communicative space of social reality changes its structure so that we can talk about the transition to a new social state. The concept of modernity means an emergence of a new learning subject, a new reader, a new viewer, and finally, a new citizen surrounded by a huge number of new things. In order to trace the qualitative changes of the space-time continuum, first of all, such characteristics as visual dominants should be identified while they form a new balance of the visible and the invisible in the society, namely, what is allowed to be represented in the public, and what is not given such an opportunity. "The new entertainment" is based on a particular reading of social dialectics of visibility/invisibility. Most of what was previously a taboo or was thought about merely as intelligible or as a kind of a model of the future is visualized today, and on the other hand, all invisible, ugly, old, sick, provincial is excluded from the sphere of public representation.
Modern everyday life is a quite dynamic phenomenon associated with the emergence of new qualities of social life: technological changes, globalization, consumer practices, flexible forms of work, mediatization characterized by "abundance of visual images". The emergence of new information technologies and forms of communication leads to a counterintuitive situation: "real life" is not present in daily life anymore. According to H. Lefebvre, in today's consumer society there is a tension between satisfaction and anxiety that inevitably generates escapism, desire to escape from everyday life. The mechanisms of mass culture ensure this desire with the help of media channels: TV, video and the Internet, advertising. The emergence of new online communities creates a new lifestyle, a diverse online world, with a multiplicity of identities and vivid experiences with a clear advantage over the world of conventional, profane existence, where a person has a boring, monotonous life. Today, a number of such life situations are: risk, overpressure, tactile touch appear as super values, which result in a whole range of social phenomena: from extreme hobbies to sadomasochistic clubs. This is the story of the film "The Bothersome Man" (directed by Jens Lien). The hero lives in a situation of total comfort and tolerance, but he suffers from an excess of guaranteed peace and security; having despised everything he seeks for something authentic: natural odor of bread, a sense of danger, risk, pain and blood.

Many researchers conclude that the interest in the study of everyday life in the second half of the $20^{\text {th }}$ century coincided with the "visual turn" in the humanities, which drew attention to "externally observable face of everyday life" having recognized in it, according to P. Sztompka, "a strategic research resource for the analysis and explanation of everyday life". The significance of this problem is determined by the fact that 
visuality (photography, film, graphic design, visual media images) is not just a supplement to the verbal forms of representation of the world. It is a basic mode of contemporary culture existence, the general principle of structuring its forms. "The visual culture is not just a part of our everyday life, it is the daily life itself". Visuality becomes a significant factor in the construction of social practices: social interaction of groups and elites, social mimesis, imitation and socialization, co-existence with the Other. Our cultural identity is formed in the surrounding visual field: $\mathrm{TV}$, the Internet, glossy magazines, glamorous press.

The fundamental point of transformation of the cultural discourse of everyday life has become a different approach in the use of visual information. In the epoch of hand-made image both painting and graphics were inseparable from the space-time of the viewers looking at them, visual perception was available for a narrow circle of connoisseurs, or a small circle of people. Today, with the development of new (digital) media not only the functions and the status of images have changed, as Walter Benjamin notes in his major paper "The Work of Art in the Age of Mechanical Reproduction", but also a lifestyle and habits of modern man, the ways he interacts with the media and communication (Zvereva, 2012). "The visual turn", which manifests itself in the growing role of images in contemporary culture, shows that images are not just a part of our everyday life, they are included in its fabric, along with posters, slogans and advertisements, they form new visual practices. In the $20^{\text {th }}$ century, visuality became the guiding principle of all modern culture, now it is based not on the linear writing, but on the flow of images on the screen, which easily includes a spoken language, animation, written texts, and much more.

The Western philosophical tradition distinguishes between "visibility" and "reality", "things" and their "designation". V. Flusser shows how in the course of the history of culture, from the era of magic development of the world to its rational comprehension, the cycles of the trust/ mistrust to the visual have been changing. In the Middle Ages, Plato's ideas about the unreliability of the visual image ("being by the opinion") are replaced by understanding of the sacredness of its nature. During this period, the image is regarded as an approximation to the truth, and man in front of the image (icon) is able to transform his everyday experience and relive his own existence as something different, sacred. That is why images should be the more transparent the better, in order not to interfere with the presence of essence. "The game of visibility" in the pre-modern era has never undermined the sense of rootedness in being, its ontological security. In the modern era with "the spread of subjectivity", the process of "weakening the reality" began, hiding it behind a variety of images and their interpretations. And philosophy, and the arts have faced the problem of the "crisis of representation" when symbols and images have lost their reference, and the distance between the imaginary and the real has been removed as a result of awareness that objectivity (reality) depends on human imagination and design.

The world of "phenomena" - signs, images and interpretations - becomes the world of media and the reality acquires the features of media reality (Savchuk 2013). It is symptomatic that in this new situation, the dominant role in everyday life belongs to media channels: TV, video and the Internet. The society becomes fully modern, when its main characteristic is information with the image, its production and consumption being the most essential part of it. The perception of the world becomes more mediated through the images of the world. It may be noted that the advent of the new visual era is expressed in shifting the verbal ways of perception towards visual, imaginative ones. Such media as cinema, advertising, 
television, photography become the main means of communication, and overshadowing the word. They directly communicate man and information or event by the visual means. In general, visual images design and shape our understanding of the world. Cinema, TV and the Internet in their interaction are the main basic visual cultural forms that reflect the permanent process of society modernization and qualitative change of the everyday communication, i.e. the everyday practices of human communication. "The great visual leap" or qualitative visual turn in the everyday communications consists not only in expansion of the information flow, but also in a certain internationalization of the information field.

The process of visualization of contemporary culture is complex and contradictory: on the one hand, there is a continuity of communication technologies based on "the expansion of the vision", on the other hand there is a transformation of the visual image into a new iconicness, which is an artificially constructed mosaic introducing the individual in the world of social experience. Being the product of cultural design, visual reality is subject to interpretation or "reading" to the same extent as any verbal text that undergoes these procedures. The problem is that there is no universal method or approach to analyze visual images, the researchers note "our limited ability to talk about the images of the modern world, mainly media, high-speed and elusive" (Aronson, 2007). Famous researcher of the visual J. Crary believes that "the increased interest to the visual speaks only for the fact that the moment has been missed: we are always late with the definition of the discipline, if its subject is view" (Petrovskaia, 2012). Moreover, the existence of many language structures (iconic turn, pictorial turn, imagic turn, visual turn), which are often considered as synonymous, suggests difficulties with terminology connected with determining not only the specifics of the image as a medium, but also with the problem of institutionalization of the new discipline "visual studies". The study of imaginary and visuality allows to distinguish between different theoretical approaches: "interpretative" (W. Mitchell, S. Hall, N. Mirzoev), according to which the image is understood as "cultural representation", a visual construct mediated by social and ideological practices, and "unrepresentative" (N. Thrift, C. Moxie, G. Balting) considering the image as a presentation based on its sensuous integrity and immediacy, as well as "the manner in which it is working its magic on the viewer" (Moxey, 2008). Such researchers as K. Moxey insist on the ability of visual images to not only actively intervene in the daily experience and design it, but also to live independently, without being merely illustrations or inert means for broadcasting ideas or opinions. Visual images, even without any aesthetic value, can cause a variety of feelings and emotions, return us to ages and space we will not be able to visit again. Furthermore, modern digital and replicated images generate special "I-havealready-seen-it-before" situation before meeting what have been really seen. D. Elkins argues that non-artistic images can be as expressive and vivid, as the traditional objects of art history. Moreover, they act as "a kind of indices of cultural values, monuments of cultural memory, centres of ritual actions" (Krutkin, 2011).

The existence of the visual image implies the dialectics of the internal and the external, of presence and absence, therefore during the study of the visual image its presentative and representative nature should be considered. According to K. Moxey, "the status of the image as a presentation is as important as the informative content" (Moxey, 2008). Therefore, during the study of the visual phenomenon it is important to understand how visuality did change under the influence of modern media, to identify 
the methods that images apply to "take over" us and form stable patterns of everyday behavior. Despite the difference in understanding the image, these theories are close due to the interest to the material nature of the image, the material medium, recognition that visual images cannot be studied separately from the media. In other words, the argument about the visual should be inscribed in a much broader context, particularly in the context of interdisciplinary studies analyzing media images, that will "allow to consider a wide range of social and psychological parameters" that occur in everyday life.

It is noteworthy that the paradigm of contemporary culture is associated not just with a quantitative increase in new images, but with its radical change, i.e. the global transformation of the cultural discourse from the textual to the visual (from the rational approach to the "philosophy of presence"). The composer and musicologist Vladimir Martynov says, "slipping out from the power of the word is not a temptation, but the fact, which can be interpreted as a temptation, but thereof it still does not cease to be the fact. The inevitability of imposing us this fact results from the situation that the age we live in has coincided with the time when the verbally oriented paradigm of culture is substituted by the visually oriented paradigm. The power of the text is replaced by the power of the image. The power of ideologems is replaced by the power of hieroglyphems, and ideology is replaced by glamour: a glossy picture showing us how to live. However, this transition is not a movement to some archaic-mythological "word-for-word". This is a movement to some unknown "afterword" state of civilization. It seems to me that there is no way we can interfere with this movement" (Nilogov, 2009).

New media give rise to new ways of social interaction and communication, which are mediated through the exchange of visual images, photographs, likes. In other words, there is a new "collective visual experience" and "network" forms of existence of mass values. Typically, the social media research begins with the analysis of the language worldview of users, genres and formulas of conversations of different online communities. In the era of mass replication of visual images, democratization of their production and consumption, their impact on the various spheres of individual life, the everyday cultural content, especially the media, is filled with individual visual storytelling or author's narrations. Analysis of Instagram, a popular mobile application, which allow to record and exchange everyday life events, indicates that visual images can be a form of communication. As a result of the system change of the practices of interaction between people, this application out of simple entertainment has become an essential element of everyday life and everyday communication. Amateur photos posted in the social network include a variety of situations of everyday existence (food, consumption, family relationships, travelling, holidays). Users communicate by means of visual images, which replaces the exchange of text units, saves speech efforts and allows to instantly record what happens daily. Today, a visual range often serves as the narrator, replacing and complementing the susceptibility of the text. The usual course of everydayness, inability to articulate ordinary relations is clearly set both visually and in space and time. Users are shown a kind of "a documentary diary" of events, the value of which is in this capture. As the researchers note (Zvereva, 2013) of speech practices of online communities, users of social networks promote several basic ideas: "my mobility", "my creativity" and "my success", which are a continuous process of selfidentification through the story. Visual content in Instagram is peculiar due to "lifestyle": a demonstration of the attributes of a beautiful life, personal photos (children, holidays, family), 
selfie, a self-portrait photograph taken with a camera phone. Self-documenting in the Internet has become truly viral (16 billion photos), and ordinary people have become paparazzi and celebrities, and stars are striving to emphasize the fact that they are just ordinary people engaged in everyday activities. In digital reality, all people are interconnected and tend to form a community around values and images. Visual images broadcast social roles and hierarchies of values. Visualization of the image of social success leads to "democratization of narcissism": we want to be seen, and we want our actions to be approved by others. Media environment creates a field of endless identities where people are captured by images (self-ideals), images of the self as an imaginary twin. And such a twin is created in accordance with the screen image specified by fashion and advertising. It may be noted that modern communication is increasingly inclined to simplify the language of communication, in particular to reduce the symbolic content to a flat sign, "an icon", "a smiley", an image.

Users of social networks tend to socialize every step in a new way, it is important to record what they have read, listened and watched, where and who they have met. Today we see the flowering of micro narrations: stories about oneself that are created with the help of visual images. Each message in the Internet is accompanied by "a picture", "an iconogramme", which is a kind of a demonstration or announcement of the news. It is enough for the user to go from one picture to another, and they will already know what happened. This kind of "logotypization of events" leads to the fact that visualization becomes, according to Roland Barthes, "information-fellow traveler" and, in fact, compensates insignificance of the reported event. Moreover, the visual message does not have to be interpreted, it is characterized by efficiency, instant clarity that provides fast communication processes.
On the other hand, there is a certain kind of voyeurism, i.e. growing interest to the diverse experience of others and what it has to offer. Voyeurism becomes a kind of a symptom of modern society. According to S. Sontag, the omnipresence of images has led, to "the establishment of chronic voyeurism relations between man and the world", whereby all events are at the same level and have the same meaning" (Sontag, 2013). Looking through the photos of another person, a voyeur is only a bystander, his desire to live is replaced by the desire to imitate. In the new media, the boundary between the observer and the world is transparent, the secret, private space is lost, replaced by public space of insignificance. According to Giddens, "the forms of life created by modernity have torn us from all traditional types of the social order have done it in a way that has no historical precedent ... In qualitative terms they have managed to change the most intimate and deeply personal characteristics of our everyday existence" (Giddens, 2004) .

Thus, the desire to document life, to record something momentary and trivial, to have a kind of visual diary of private life exposed for public viewing, results in the change of personalization and identity algorithms. With the development of new media, there is a significant shift in anthropology: Me alone as a reality does not exist any longer, there is a "multi-personality" playing different roles and having many identities.

Visual images are not ephemeral, the force of their impact is so great that there is no coincidence they are built into consumption mechanisms. A specific feature of modern media is an immersive, active influence on the emotions of the viewer, creation of the presence effect and participation in what is happening on the screen. Visual imagery here plays the major role while it supports the narration. According to O. Grau, "if earlier images were caused by exceptional events, cults, and later art and museums, in the age of 
cinema, television and the Internet, we are closely tangled in images. The image is embedded in new segments, not only TV turns into a thousandchannel field of zapping, big screens are placed in our cities, mobile phones send microfilms in real time. We are experiencing the ascent of the image to the computer-production virtual stereoscopic image, which is able to become "apparently" autonomous and truly expand visual-sensory sphere" (Grau, 2012).

Due to the use of television formats, such as talk shows and reality shows, viewers not only watch programmes they are involved and interested in them during viewing. The continued interest to such formats confirmed by surveys of sociologists, is a form of socialization of the viewer while observing the experience of others, watching how they cope with solving different life problems, it allows the viewer to search for new options and feel confident in the situation of growing uncertainty. Moreover, within the framework of talk shows there is "legitimization of the public discourse about private things", when "something one cannot talk about is expressed and discussed, something shameful becomes acceptable, or even decent, and repulsive secrets turn into a source of pride" (Chernykh, 2013). Television more clearly than other media shows that people want to watch, it is interesting for them how others observe, while remaining invisible. Modern methods of communication form the overall experience of media consumption: typical situations are simulated, new roles and options of behaviour are tested for the viewer/consumer, the degree of their success and affordability is checked.

Invasion of the daily "flow of images" has led to a paradoxical situation: "We do not look at the images, but the images are looking at us" (Savchuk 2013). Most of what has formed our everyday experience is already "formatted" by visual images, whether it is shopping, searching of a hotel, chatting with friends. Visual images create a kind of a veil between man and the world, they dictate the visual dominants, form the new balance of the visible and invisible, namely, what is allowed for representation in the public space, and what is not. The emergence of new media radically breaks the connection between the physical space where the person resides, and the communicative space in which they communicate. This suggests the coagulation of distances, in a sense, their "death". Moreover, time due to new media also becomes singular and loses its temporality, for the modern consumer the time of information search coincides with the time of viewing this information. The space where public communication was carried out, is replaced by audio-visuality od screens and digital reporting devices, which are gradually becoming "vision machines". New media have strongly influenced both the everyday practices of information consumption, and the routine actions of users, most of which - services, payment of utility bills, purchase, etc. -are now implemented in the virtual world. The discourse changes, so do social practices, and on the contrary, new practices exist in the new discourse.

Modern media images are replicated, mobile, immersive, addressed directly to the physicality of man, his sensory experience. The body in the era of new media has become a kind of an interface, "living media" that has got additional opportunities associated with "advanced vision". Optics of an eye and vision are magnified by media technologies that allow you to make virtual and imaginary movements, see in detail what was hidden before and enter what was previously impossible to enter.

Daily life includes a variety of visual media texts, most of which are consumed "on the go", in motion. Stationary media are replaced with lightweight, portable and multi-functional media such as mobile phones, laptops. Therefore, 
we can say that the mobility of people, among other factors, is interrelated with the mobility of media technologies. The Internet has created new forms and new modes of vision. Unhurried contemplation is replaced by "vision in motion", which transforms the space into a kaleidoscope of changing images. The Internet programmes our consciousness to read episodic, fragmentary, up to the most elementary formal units outside of any framework of the common. Such new "automobile perception" typical for modern media society is similar to cinematographic "time-motion" described in the works of Gilles Deleuze (Deleuze, 2004). From the perspective of media research, the intersection of mobile people and mobile media creates situations related to the definition of new space-time everyday practices that require specific in-depth study.

\section{References}

1. Aronson, A. (2007). Kommunikativnyi obraz (Kino. Literatura. Filosofiia) [Communicative Image (Cinema. Literature. Philosophy)]. Moscow: Novoe literaturnoe obozrenie, p. 39.

2. Certeau, M. (2013). Izobretenie povsednevnosti.1. Iskusstvo delat' [The Practice of Everyday Life.1. The Art of Doing] Saint Petersburg: Publishing House of European University in St. Petersburg, p. 105.

3. Chernykh, A.I. (2013). Media i ritualy [Media and Rituals]. Moscow; St. Petersburg: Universitetskaya kniga, p. 134.

4. Deleuze, G. (2004). Kino 1: Obraz-dvizhenie. Kino 2: Obraz-vremia. [Cinema 1: MovementImage. Cinema 2: Time-Image]. Moscow: Ad Marginem, 622 p.

5. Flusser, V. (2008). Za filosofiu fotografii [Towards a Philosophy of Photography]. Translated from German. St. Petersburg: Publishing House of St. Petersburg. University, p. 17.

6. Giddens, A. (2004). Uskol'zaiushchii mir. Kak globalizatsiia meniaet nash mir [Runaway World: How Globalization is Reshaping Our Lives]/ translated from English into Russian. Moscow: Publishing House Ves' Mir, p. 115.

7. Grau, O. (2012). Fantasmagoricheskoe vizual'noe koldovstvo XVIII stoletiia i ego zhizn'v media iskusstve. [Phantasmagoric Visual Wizardry of the $17^{\text {th }}$ Century, and Its Life in the Media Art]. Mezhdunarodnyi zhurnal issledovanii kul'tury [International Journal of Cultural Studies], 1 (6), 103.

8. Gudkov, L.D. (2012). Ex Cathedra: Sovremennye metody izucheniia kul'tury [Ex Cathedra: Modern Methods of Studying Culture]: Collection of Articles. Moscow: Russian State University for the Humanities, p. 31.

9. Kharkhordin, O.V. (2007). Pragmaticheskii povorot: sotsiologiia L. Boltanski i L. Teveno. [The Pragmatic Turn: Sociology of L. Boltanski and L. Thévenot]. Sotsiologicheskie issledovaniia [Sociological Studies], 1, 32.

10. Kozlova, N.N. (1998). Sotsial'no-istoricheskaia antropologiia [Socio-historical anthropology]. Moscow: Kliuch-S, p. 18.

11. Krutkin, V.L. (2011). Kit Moksi: o vizual'nykh issledovaniiakh i ikonicheskom povorote [Keith Moxey: About Visual Research and the Iconic Turn] // Vestnik Udmurtskogo universiteta [Bulletin of Udmurt University], 2, 32.

12. Kurennoi, V. (2003). Media: sredstva v poiskakh tselei [Media: Means in the Search for Objectives]. Otechestvennye zapiski. 4, Available at: http://www.strana-oz.ru/2003/4/media-sredstvav-poiskah-celey (accessed 22.09.2014). 
13. Lefebvre, H. (2007). Povsednevnoe i povsednevnost' [The Everyday and Everydayness]. Sotsiologicheskoe obozrenie [Sociological Review] 3, 34

14. Lubbe, H. (1994). V nogu so vremenem. O sokrashchenii nashego prebyvaniia $v$ nastoiashchem [Apace with Times. Reduction of Our Presence in the Present]. Voprosy filosofii [Issues of Philosophy], 4, 94.

15. Moxey, K. (2008). Visual Studies and Iconic Turn Journal of Visual Culture. Los Angeles; London; New Delhi; Singapore: Sage. Vol. 7(2). p. 141.

16. Moxey, K. (2008). Visual Studies and the Iconic Turn. Journal of Visual Culture. 7 (2), 131146.

17. Nilogov, A. (2009). Vyskal'zyvanie iz-pod vlasti slova. Vladimir Martynov o protivostoianii ikonotsentrichnosti i literaturotsentrichnosti [Slipping Out From the Power of the Word. Vladimir Martynov on the Confrontation of Iconocentricity and Literocentricity]. Knizhnoe obozrenie Ex libris NG.14.05, 2.

18. Petrovskaia, E.V. (2012). Teoriia obraza [The Theory of the Image]. Moscow: Russian State University for the Humanities, p. 15.

19. Savchuk, B. (2013). Mediafilosofiia. Pristup real'nosti [Media Philosophy. The Attack of Reality]. St. Petersburg: Publishing House of Russian Christian Humanitarian Academy, p. 338.

20. Savchuk, V. (2013). Antologiia mediafilosofii [Anthology of Media Philosophy] St. Petersburg: Publishing House of Russian Christian Humanitarian Academy, p. 312.

21. Sontag, S. (2013). O fotografii [About Photography]. Moscow: Ad Marginem p.5

22. Zvereva, V. (2012). Setevye razgovory. Kul'turnye kommunikatsii v Runete [Network Conversations. Cultural Communication in RuNet]. Bergen: University of Bergen, p. 4.

23. Zvereva, G.I (2013). Samoidentifikatsiia v sotsial'nykh media [Identity in Social Media]. Available at: http://postnauka.ru/video/19518 (accessed 2.10.2014).

\title{
Трансформация повседневности в современном медиаобществе
}

\author{
А.В. Дроздова \\ Гуманитарный университет \\ Россия, 620144, Екатеринбург, ул. Сурикова, $24 a$
}

Современное общество характеризуется появлением новых форм соииальности, сетевых способов коммуникации, которые привели к «переоткрытию» повседневности в современном гуманитарном знании. На смену метафизическим конструкииям прошлого века пришел поиск новых оснований для изучения «реальности» повседневности. Признавая поливариантность мира, его неоднородность, социальная теория открыла сложную структуру повседневности, ее несводимость к некой абстрактной характеристике. Поскольку именно в повседневном мире человека проявляются присущие обществу трансформачии, то множественность его опыта, практик стали предметом междисциплинарного анализа.

В настоящее время с развитием новых медиа и возростей плотностью контактов в повседневной жизни произошло изменение не только самой природы сочиальной коммуникации, но и сферы воздействия визуальной информации. Визуальность стала важной 
частью повседневной жизни человека, ее образы репрезентируют стиль жизни и способы взаимоотношений, конструируют восприятие и структуру сознания человека как особый способ его видения мира.

В эпоху «реальности медиа» повседневность утрачивает свою устойчивость и стабильность, непрерывно подвергаясь трансформации под влиянием сверхскоростных, мобильных визуальных образов. Визуальные образы выступают в роли своеобразных паттернов, образцов повседневных действий. Благодаря «технической воспроизводимости» образы быстро интегрируются в повседневную жизнь, замещзая непосредственный опыт, порождая феномен симуляции реальности. Конструируя и подменяя реальность, упрощая язык общения, визуальные образы, по сути, становятся своеобразным универсальным культурным кодом, порождая новые способы социального взаимодействия и коммуникации, выступая при этом условием формирования соцчиальных общнностей.

Ключевые слова: повседневность, визуальность, самоидентификация, новые медиа, публичное/приватное.

Научная специальность: 09.00.00 - философские науки. 